\title{
NGHIÊN CỨU XÂY DỰNG QUY TRÌNH PHÂN TÍCH ĐA HÌNH rs36211723 TRÊN GEN MÃ HÓA PROTEIN C LIÊN KẾT MYOSIN Ở NGƯỜI BÊ̂NH CO' TIM PHÌ ĐẠI
}

\author{
Phạm Thị Hồng Nhung*, Nguyễn Phương Thảo*, \\ Đỗ Thị Lệ Hằng*, Vũ Thị Thơm*, Đinh Đoàn Long*
}

TÓM TẮT

Đặt vấn đề: Bênh cơ tim phì đại (BCTPĐ) là bệnh di truyền phổ biến, do gen trội trên nhiễm sắc thể thường quy định. Đột biến trên các gen mã hóa protein đốt cơ (sacromere) của sợi cơ tim đước cho là nguyên nhân di truyên chính gây ra BCTPĐ. Trong đó, đa hình rs36211723 thuộc gen mã hóa protein C liên kết myosin (MYBPC3) chiếm tỉ lệ lớn trong các đa hình gây bệnh cơ tim phì đại ở người Việt Nam. Vì vâyy, việc tiến hành xây dựng quy trình phân tích đa hình di truyền rs36211723 ở người mắc BCTPĐ là thực sự cậ्n thiết. Phương pháp: Tách chiết DNA tổng số từ mẩu máu tĩnh mach, khuếch đai gen bằng $P C R$, xác đinh kiểu gen bằng giải trình tự Sanger. Kết quả và kết luân: Quy trình phân tích đa hình rs36211723 đã được hoàn thiện. Nghiên cứu được áp dụng thành công để phân tích kiểu gen của môtt gia đình bênh nhân mắc BCTPĐ. Ngoài bệnh nhân, bố của bệnh nhân có mang đa hình này nhưng biểu hiện bệnh lý không rõ ràng, được bác sĩ khuyển cáo nên theo dõi tiến triển bệnh lý chặt chẽ để hạn chế biến chứng nặng xảy ra.

Tư khóa: rs36211723, gen MYBPC3, bệnh cơ tim phì đại, giải trình tự Sanger.

\section{SUMMARY}

ESTABLISHING THE PROCOTOL FOR

\section{DETECTING rs36211723 POLYMORPHISM OF} MYBPC3 GENE FROM BLOOD SAMPLE OF HYPERTROPHIC CARDIOMYOPATHY PATIENTS

Objective: Hypertrophic cardiomyopathy is a common inherited disease, regulated by autosomal dominant genes. Mutations in the genes encoded for sarcomere proteins of the myocardial fiber are considered to be the primary genetic cause of hypertrophic cardiomyopathy. In particular, the rs36211723 polymorphism in the cardiac myosinbinding protein $C$ gene (MYBPC3) accounts for a large proportion of the polymorphisms causing hypertrophic cardiomyopathy in Vietnamese people. Therefore, identification of rs36211723 polymorphism of Vietnamese hypertrophic cardiomyopathy patients is really necessary. Methods: total DNA extraction from venous blood samples, gene amplification by PCR, and genotype determination by Sanger sequencing were applied. Results and conclusion: An optimized protocol for detecting polymorphism rs36211723 has

*Trường ĐH Y Dước, Đại học Quốc gia HN

Chịu trách nhiệm chính: Đinh Đoàn Long

Email: dinhdoanlong.smp@gmail.com

Ngày nhận bài: 8/1/2021

Ngày phản biên khoa học: 5/2/2021

Ngày duyệt bài: $1 / 3 / 2021$ been established. To primary test the protocol, genotypes of a family members of 19 -year-old female patient with hypertrophic cardiomyopathy were tested. Rs36211723 polymorphism of MYBPC3 gene was recorded in a female patient and her father that shown the meaning of our method in detecting this polymorphism for hypertrophic cardiomyopathy patients.

Keywords: rs36211723, MYBPC3 gene, hypertrophic cardiomyopathy, Sanger sequencing

\section{I. ĐĂT VẤN ĐỀ}

Bệnh cơ tim phì đại (BCTPĐ) là bệnh lý tim mạch di truyền thường gặp, đặc trưng bởi sự dày lên bất thường của thành cơ tim. Theo hướng dẫn của Hội Tim mạch châu Âu về chẩn đoán và điều trị BCTPĐ (ESC) năm 2014, dấu hiệu của bệnh trên siêu âm tim hoặc chụp cộng hưởng từ là độ dày thành tâm thất trái $\geq 15 \mathrm{~mm}$, bệnh nhân khồng có nguyên nhân thứ phát như hẹp động mạch chủ, tăng huyết áp. Đây là căn bệnh có tính chất toàn cầu với số người mắc lên đến 20 triệu người, phân bố tại 122 quốc gia, ở đa dạng các chủng tộc và trên cả hai giới. Tỷ lệ mắc bệnh cơ tim phì đại ước tính là $1 / 500$ $(0,2 \%)$ cho dân số toàn thế giới[1]. Tuy nhiên theo nghiên cứu của Christopher Semsarian và cộng sự năm 2015, tỷ lệ người mang gen gây bệnh cớ tim phì đại có thể lớn gấp 2,5 lần so với con số ước tính này[2]. Tại Việt Nam, số lượng người mắc BCTPĐ chưa được thống kê cụ thể, tuy nhiên số người bệnh ước tính có thể lên đến 180.000 người, một con số không hề nhỏ với một bệnh lý có thể gây tử vong như BCTPĐ. Biểu hiện lâm sàng của $B C T P Đ$ rất đa dạng, từ không có triệu chứng, khó thở, tức ngực cho tới suy tim, đột tử, gây khó khăn cho việc phát hiện và điều trị bệnh sớm. Đa số bệnh nhân mắc BCTPĐ chỉ được phát hiện khi đã có biến chứng nặng[3]. Chính vì vậy, việc phát hiện sớm bệnh là rất quan trọng trong chẩn đoán, điều trị và quản lý BCTPĐ một cách hiệu quả, đặc biệt với người nhà của những bệnh nhân BCTPĐ̇.

$\mathrm{BCTPĐ}$ là bênh di truyền do gen trội nằm trên nhiễm sắc thể thường, trong đó một alen đột biến thường đủ để gây bệnh. Hơn 2000 đột biển ở ít nhất 20 gen đã được xác định ở bệnh nhân mắc $B C T P Đ$, phổ biến nhất là các đột biến thuộc gen mã hóa tổng hợp protein của các đốt cơ 
(sarcomere) trên sợi cơ tim hoặc đĩa Z[4]. rs36211723 là một trong những đột biến chính ở gen mã hóa cho protein $C$ liên kết với myosin (MYBPC3), thay thế nucleotide $G$ thành $A$ (c.2308G >A, pAsp770Asn) và tạo ra dạng protein bị cắt ngắn, dẫn đến giảm khả năng vận động bơm máu của tim[5]. Chính vì vậy, chúng tôi thực hiện nghiên cứu này nhằm mục đích thiết lập quy trình nhân dòng và phân tích đa hình rs36211723 của gen MYBPC3 bằng giải trình tự theo nguyên lý Sanger.

\section{II. ĐỐl TƯƠNG VÀ PHƯƠNG PHÁP NGHIÊN CỨU}

2.1. Đối tượng nghiên cứu: 10 đối tượng nghiên cứu được lựa chọn bao gồm 06 người khỏe mạnh, 04 người trong gia đình bệnh nhân mắc BCTPĐ được chẩn đoán tại Viện Tim Mạch, Bênh viện Bach Mai. Thời gian lấy mấu từ 12/2018 đến 07/2019. Nghiên cứu tuân thủ theo quy định và được thông qua bởi Hội đồng đạo đức của Khoa Y Dược, ĐHQG Hà Nôi.

2.2. Thu thập và bảo quản mẫu máu: Mẫu máu toàn phần lấy từ tĩnh mạch của đối tượng nghiên cứu được chống đông bằng EDTA, bảo quản ở $-20^{\circ} \mathrm{C}$ cho đến khi sử dụng.

Tách chiết DNA tổng số: Sử dụng E.Z.N.A blood DNA Mini Kit (Omega, Mỹ) theo quy trình khuyến cáo của hãng. DNA tổng số được kiểm tra và đánh giá thông qua điện di trên gel agarose và đo hấp thụ quang tại bước sóng $260 \mathrm{~nm}$ và $280 \mathrm{~nm}$.

2.3. Nhân dòng đoạn gen mang đa hình rs36211723: Để có quy trình nhân dòng đă̆c hiệu và ổn định, chúng tôi xác định nhiệt độ gắn mồi, nồng độ mồi và nồng độ DNA hoạt động tối ưu trong phản ứng PCR sử dụng $0.2 \mathrm{mM}$ dNTP Mix, 0,03 u/ $\mu$ l Phusion DNA Polymerase (Thermo Scientific, Mỹ). Khoảng nhiệt độ gắn mồi khảo sát từ $50-65^{\circ} \mathrm{C}$, khoảng nồng độ mồi từ $0,1-0,9$ $\mu \mathrm{M}$, khoảng nồng độ DNA từ $10-100 \mathrm{ng} / \mu \mathrm{l}$. Sản phẩm PCR được điện di trên gel agarose 1,5\%, cùng thang chuẩn Ruler 100 bp Plus DNA Ladder (Thermo Scientific, Mỹ).

Cặp mồi được tự thiết kế sử dụng phần mềm PerlPrimer version 1.1.14. Cặp mồ tự thiết kế được đặt tổng hợp tại hãng PhuSa Biochem (Việt Nam) với trình tự mồi xuôi: $5^{\prime}-$ CTGACTTGGATCTCACCC-3' và mồi ngược: $5^{\prime}$ ACCATCTTCTCAGCCTCC-3'. Đoạn DNA nhân lên có độ dài 497 bp.

2.4. Xác định kiểu gen bằng phương pháp giải trinh tự: $20 \mu \mathrm{l}$ sản phẩm PCR được gửi giải trình tự tại hãng IDT (Malaysia). Kết quả giải trình tự được đọc bằng phần mềm BioEdit version 7.2.6 để xác định kiểu gen.

\section{KẾT QUẢ NGHIÊN CỨU}

3.1. Tách chiêt DNA tổng số: Nồng độ DNA tổng số thu hồi sau tách chiết dao động từ $17,7 \mu \mathrm{g} / \mathrm{ml}$ đến $34,3 \mu \mathrm{g} / \mathrm{ml}$. DNA tổng số thu được có độ tinh sạch cao với chỉ số OD260/280 từ $1,7-2,0$ chứng tỏ DNA đạt yêu cầu cho phản ứng khuếch đại đoạn gen bằng $\mathrm{PCR}$. Sản phẩm điện di cho 1 băng DNA duy nhất rõ nét cho thấy DNA tổng số thu được ít bị đứt gãy (Hình 1).

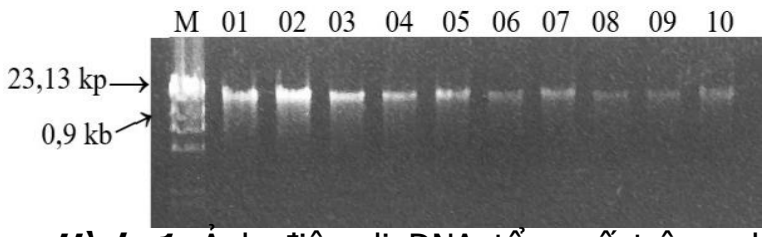

Hình 1. Ánh điện di DNA tổng số trên gel agarose 1\%. Làn M: DNA/HindIII marker. Làn 01-10: mẫu DNA tổng số thu của bệnh nhân có mã tương ứng.

3.2. Nhân dòng đoạn gen mang đa hình rs36211723: Kết quả điện di sản phẩm tối ưu nhiệt độ gắn mồi và nồng độ mồi được thể hiện trong Hình 2. Dựa trên kết quả hình ảnh băng điện di sáng rõ, không có băng phụ, chúng tôi lựa chọn nhiệt độ gắn mồi tối ưu là $60,5^{\circ} \mathrm{C}$. Như vậy, chu trình nhiệt cho phản ứng PCR gồm 3 giai đoạn: biến tính ban đầu $95^{\circ} \mathrm{C}$ trong 3 phút; 35 chu kỳ: $95^{\circ} \mathrm{C}$ trong 30 giây, gắn mồi ở $60,5^{\circ} \mathrm{C}$ trong 45 giây, $72^{\circ} \mathrm{C}$ trong 1 phút; thời gian kéo dài cuối $72^{\circ} \mathrm{C}$ trong 5 phút. Nồng độ mồi hoạt động tối ưu là $0,3 \mu \mathrm{M}$. Về nồng độ DNA, chúng tôi thấy rằng tại nồng độ mồi $0,3 \mu \mathrm{M}$, các vị trí băng điện di tương ứng với nồng độ DNA từ 10100 ng/pl đều lên rõ, không có băng phụ.
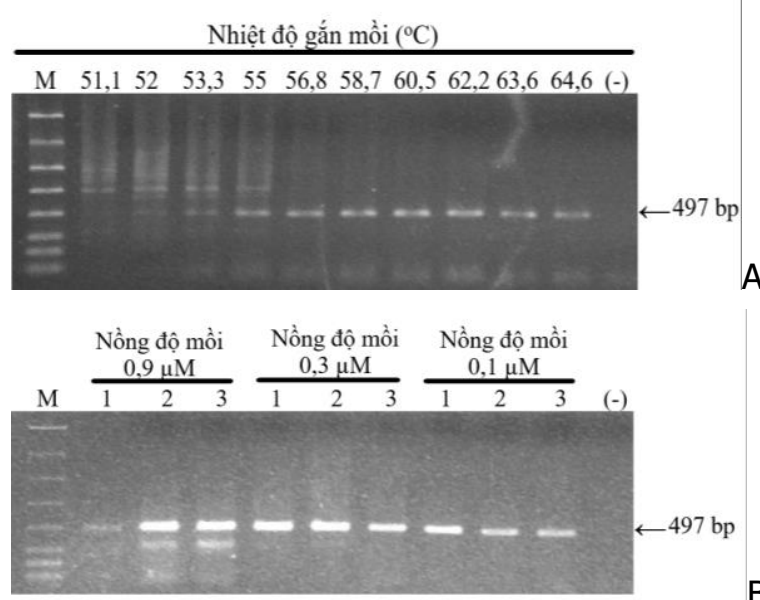

Hình 2. Ảnh điện di trên gel agarose 1,5\% sản phẩm PCR tối ưu nhân dòng đoạn DNA chứa rs36211723. A: Tối ưu nhiệt độ gắn mồi. B: Tối 
ưu nồng độ mồi và nồng độ DNA hoạt động. 1 : nồng độ DNA $100 \mathrm{ng} / \mu \mathrm{l}$. 2: nồng độ DNA 50ng/ul. 3: nồng độ DNA $10 \mathrm{ng} / \mu \mathrm{l}$. M: marker GeneRuler TM 100 bp DNA Ladder. (-): Đối chứng âm.

3.3. Giải trình tự xác định kiểu gen: Dựa vào kết quả giải trình tự, chúng tôi xác định

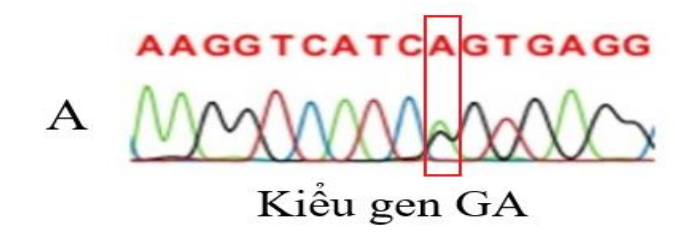

được trong số 10 đối tượng tham gia nghiên cứu, 8 người có kiểu gen đồng hợp kiểu dại GG, 2 người có kiểu gen dị hợp $\mathrm{GA}$, không người nào có kiểu gen đồng hợp đột biến AA. Trong đó, 2 người mang kiểu gen dị hợp GA là bệnh nhân và bố của bệnh nhân. Kết quả giải trình tự đoạn DNA chứa rs36211723 được thể hiện trong Hình 3.

B

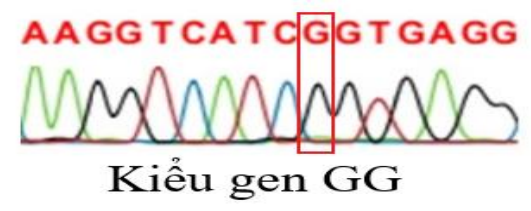

Hinh 3. Kêt quả giải trinh tự đoạn DNA chứa đa hỉnh rs36211723. Phần đóng khung là vị trí đa hinh rs36211723

\section{BÀN LUÂN}

Kết quả nghiên cứu cho thấy quy trình phân tích đa hình rs36211723 của chúng tôi ổn định trên 10 mẫu nghiên cứu. Trong quy trình này, chúng tôi tách chiết DNA tổng số từ mẫu máu tĩnh mạch của đối tượng nghiên cứu. Đây là dạng mẫu bệnh phẩm thông dụng và dễ dàng thu thập tại các cơ sở khám chữa bệnh. Một số mẫu cho nồng độ DNA khá thấp (mẫu có nồng độ DNA thấp nhất là $17,7 \mu \mathrm{g} / \mathrm{ml}$ ). Tuy nhiên, nổng độ DNA trong khoảng $10-100 \mu \mathrm{g} / \mathrm{ml}$ đều cho băng điện di sáng rõ (Hình 2), chứng tỏ phản ứng nhân dòng đoạn gen có độ nhạy cao kể cả với nồng độ DNA thấp. Như vậy, quy trình phân tích đa hình rs36211723 của gen MYBPC3 tối ưu bao gồm: nhiệt độ gắn mồi là $60,5^{\circ} \mathrm{C}$, nồng độ mồi hoạt động là $0,3 \mu \mathrm{M}$, nồng độ DNA hoạt động trong khoảng $10-100 \mu \mathrm{g} / \mathrm{ml}$. Quy trình tối ưu hóa được thiết lập giúp tiết kiệm thời gian, chi phí và nâng cao hiệu quả cho cổng tác phân tích đa hình gen, phục vụ cho các nghiên cứu tiếp theo.

Trong 10 đối tượng tham gia nghiên cứu chỉ có 2 người mang kiểu gen dị hợp GA, bao gồm bệnh nhân được chẩn đoán mắc BCTPĐ bởi Viên Tim Mạch, Bệnh viện Bạch Mai và người bố của bệnh nhân này. Do $B C T P Đ$ di truyền theo kiểu gen trội trên nhiễm sắc thể thường nên người mang gen bệnh có $50 \%$ nguy cơ truyền lại đột biến này cho con. Như vậy, đột biến thay thế đơn nucleotide c.2308G>A tại vị trí đa hình rs36211723 này có thể là nguyên nhân di truyền gây $\mathrm{BCTPĐ}$ biểu hiện từ sớm ở bệnh nhân và BCTPĐ biểu hiện chưa rõ ràng ở người bố.Trước đó, đột biến này đã được ghi nhận trên nhiều bệnh nhân mắc BCTPĐ người Việt Nam [6]. Protein $\mathrm{C}$ liên kết myosin biểu hiện trong cơ tim, tham gia vào quá trình hình thành sợi dày của cơ tim bằng cách liên kết myosin và titin, góp phần vào sự ổn định của sacromere. Kết quả của đột biến c.2308G >A trên gen MYBPC3 là thay đổi quá trình cắt nối intron, tạo ra dạng protein bị cắt ngắn, làm thiếu vị trí liển kết giữa myosin và titin, gây giảm khả năng vận động bơm máu của tim[5]. Sự hiện diện của đột biến tại vị trí đa hình rs36211723 gợi ý cho nguy cơ mắc BCTPĐ và đưa ra yêu cầu theo dõi sự phát triển của bệnh định kỳ trên 2 đối tượng này.

Suốt thập kỷ qua, ngày càng nhiều các đột biến được tìm thấy có liên quan hoặc được chứng minh là nguyên nhân của BCTPĐ. Trong đó, phần lớn nguyên nhân của các trường hợp BCTPĐ là những đột biến trên gen mã hóa protein sacromere. Một số ít khoảng 5-10\% trường hợp BCTPĐ là do các đột biến trên gen không mã hóa protein sacromere liên quan đến bệnh lý thần kinh - cơ, rối loạn chuyển hóa hoặc hội chứng di truyền [7]. Ở bẹ̉nh nhân người Việt Nam, đột biến ở MYBPC3 được ghi nhận chiếm $38,6 \%$, có tần số đột biến cao nhất trong các dạng đột biến gây BCTPĐ được xác định[8]. Ngày nay, những khám phá về gen đã giúp chúng ta nâng cao hiểu biết về cơ sở di truyền của BCTPĐ. Bên cạnh đó, tiến bộ trong công nghệ giải trình tự gen cho phép xác định kiểu gen nhanh chóng với giá thành ngày càng hợp lý, mở ra triển vọng cho xét nghiệm di truyền phát hiện sớm BCTPĐ. Tuy vậy, tính chất đa dạng trong biểu hiện lâm sàng và sự hiểu biết chưa đầy đủ về biến thể di truyền trển gen gây $\mathrm{BCTPĐ}$ vẫn đang là thách thức cho việc giải thích các phát hiện về mặt di truyền, đòi hỏi tiếp tục những nghiên cứu tiếp theo để làm rõ chúng. Nghiên cứu xây dựng quy trình phân tích đa hình rs36211723 trên gen MYBPC3 của chúng tôi sẽ là cơ sở cho các nghiên cứu chuyên sâu với số 
lương mẫu lớn hơn về đa hình rs36211723 và mối liên quan của đa hình này với BCTPĐ trong tương lai. Chúng tôi khuyến nghị mở rộng nghiên cứu, kết hợp với dữ liệu lâm sàng để đánh giá rõ hơn tác động của của đa hình này tới biểu hiện BCTPĐ trên quần thể người Việt Nam.

\section{KẾT LUÂ̂N}

Chúng tôi đã xây dựng được quy trình phân tích đa hình rs36211723 trên mẫu máu toàn phần và áp dụng thành công với 10 mẫu nghiên cứu. Kết quả này sẽ là cơ sở cho các nghiên cứu tiếp theo về đa hình rs36211723 và đột biến gen MYBPC3, phục vụ cho chẩn đoán phát hiện sớm bệnh cơ tim phì đại trên thực tiễn.

Lời cảm ơn. Chúng tôi trân trọng cảm ơn sự tài trợ của Đại học Quốc gia Hà Nội cho đề tài mã sổ QG.18.60 để thực hiện nghiên cứu này.

\section{TÀI LIỆ THAM KHẢO}

1. Maron, B.J., et al. (2018). Global Burden of Hypertrophic Cardiomyopathy.JACC Heart Fail, 6 (5): p. 376-378.

2. Semsarian, $C_{\text {., }}$ et al. (2015). New perspectives on the prevalence of hypertrophic cardiomyopathy.J Am
Coll Cardiol,65(12): p. 1249-1254.

3. Maron, B.J., et al. (1995).Prevalence of hypertrophic cardiomyopathy in a general population of young adults. Echocardiographic analysis of 4111 subjects in the CARDIA Study. Coronary Artery Risk Development in (Young) Adults.Circulation, 92 (4): p. 785-9.

4. Maron, B.J., et al. (2018). Clinical Course and Management of Hypertrophic Cardiomyopathy. $N$ Engl J Med, 379 (7): p. 655-668.

5. Tanjore, R.R., et al.(2008). MYBPC3 gene variations in hypertrophic cardiomyopathy patients in India. Can J Cardiol, 24 (2): p. 127-30.

6. Calore, C.,et al. (2015). A founder MYBPC 3 mutation results in $\mathrm{HCM}$ with a high risk of sudden death after the fourth decade of life.J Med Genet, 52 (5): p. 338-47.

7. Elliott, P.M., et al. (2014). 2014 ESC Guidelines on diagnosis and management of hypertrophic cardiomyopathy: the Task Force for the Diagnosis and Management of Hypertrophic Cardiomyopathy of the European Society of Cardiology (ESC).Eur Heart J, 35 (39): p. 2733-79.

8. Tran Vu, M.T., et al. (2019). Presence of Hypertrophic Cardiomyopathy Related Gene Mutations and Clinical Manifestations in Vietnamese Patients With Hypertrophic Cardiomyopathy.Circ J, 83 (9): p. 1908-1916.

\section{NGHIÊN CỨU IN VITRO: SO SÁNH TÍNH KHÁNG MỎI CHU KỲ CỦA CÁC HỆ THỐNG TRÂM QUAY WAVEONE GOLD VÀ RECIPROC}

\section{TÓM TẮT}

Mục tiêu: Nghiên cứu so sánh đặc tính kháng mỏi chu kỳ của hai hệ thống trâm NiTi mới đã có mặt ở thị trường Việt Nam: WaveOne Gold (WO Gold; Dentsply Maillefer, Ballaigues, Switzerland) và Reciproc (VDW, Munich, Germany) có cùng chế độ quay qua lại. Đối tượng và phương pháp: Thử nghiệm nghiên cứu in vitro trên 08 trâm WO Gold Primary có kích thước 25 độ thuôn 7\% (25/0.07); và 08 trâm Reciproc R25 (25/0.08). Trâm được cho quay trong ống tủy nhân tạo cong $90^{\circ}$ cho đến khi gãy. Cả hai nhóm đều được điều khiển bằng cùng một máy nội nhavới chế độ quay qua lại dành riêng cho mối nhóm là WAVEONE ALL (tốc độ 350 vòng/phút) và RECIPROC ALL (tốc độ 300 vòng/phút). Thời gian từ khi bắt đầu quay đến khi gãy được ghi nhận lại. Giá trị thể hiện tính kháng mỏi chu kỳ là số vòng quay được của trâm cho đển khi gãy, được tính bằng cách nhân tốc độ quay với thời gian quay. Kết quả: Số vòng quay được cho đến khi

*Đai hoc Y Dược TP. Hồ Chí Minh

Chiu trách nhiệm chính: Lê Hoàng Lan Anh

Email: Ihlanh@ump.edu.vn

Ngày nhận bài: 3/1/2021

Ngày phản biện khoa học: 2/2/2021

Ngày duyệt bài: $1 / 3 / 2021$

\section{Lê Hoàng Lan Anh*, Phạm Văn Khoa*}

gãy của hệ thống trâm WO Gold Primary $(801,06 \pm$ $62,71)$, cao hơn có ý nghĩa so với hệ thống trâm Reciproc R25 $(648,41 \pm 31,65)$. Kết luần: Hệ thống trâmWO Gold Primary có tính kháng mỏi chu kỳ cao hơn với hệ thống trâm Reciproc R25.

Tư khóa: Tính kháng mỏi chu kỳ, quay qua lại

\section{SUMMARY}

\section{LABORATORY COMPARISON OF CYCLIC FATIGUE RESISTANCE OF WAVEONE GOLD AND RECIPROC FILE SYSTEMS}

Objectives: To compare the fatigue resistance of two new NiTi file systems in Vietnam: WaveOne Gold (WO Gold; Dentsply Maillefer, Ballaigues, Switzerland) and Reciproc (VDW, Munich, Germany) which has the same reciproccating motion mode. Materials and methods: An in vitro comparision of cyclic fatigue test of 08 WO Gold Primary (25/0.07) and 08 Reciproc R25 (25/0.08) was performed in a 90-degree curved artificial canal until failure. Both groups were controlled by a motor with reciprocating motion mode for each group: WAVEONE ALL (has a speed of 350 rpm) and RECIPROC ALL (has a speed of $300 \mathrm{rpm}$ ). The time to failure was recorded. The number of cycles to failure (NCF) for each file was calculated by multiplying the time by the rotational speed. NCF represented cycle fatigue resistance of files. Results: 